\title{
Short Communication: Dye-yielding plant resources of Maharashtra, India: A checklist
}

\author{
SONALI HINDURAO PATIL ${ }^{1}$, DILIP DAMODAR KURLAPKAR ${ }^{2}$, DATTATRAYA KRISHNA GAIKWAD \\ ${ }^{1}$ Department of Botany, Shivaji University. Vidyanagar, Kolhapur 416004, Maharashtra, India. \\ ${ }^{2}$ Koparde Mahavidyalaya. Koparde 416204, Maharashtra, India. `email: ddkurlapkar@gmail.com
}

Manuscript received: 12 September 2018. Revision accepted: 26 December 2018

\begin{abstract}
Patil SH, Kurlapkar DD, Gaikwad DK. 2019. Dye-yielding plant resources of Maharashtra, India: A checklist. Biodiversitas 20: 250-266. Natural dyes have rich variation in sources of dyestuff and possess superior aesthetic quality, which is more pleasing to the eye due to unique natural color. Because of their nontoxic effect, they are used for coloring textile, cosmetics, drugs, and various food products. Although indigenous knowledge system has been practiced over the years in the past, the use of natural dyes has diminished over generations due to lack of documentation. Also, there is not much information available on databases of either dye-yielding plants or their products. Therefore, the purpose of the present study was to document the dye yielding plant species and associated knowledge from the study area. Present study provides the first comprehensive checklist of dye yielding Angiosperms of Maharashtra and their resulting color, pigment, and distribution have also been reported. A checklist consists of 195 species distributed among 153 genera and 58 families are presented based on published literature on dye plants, various state and regional floras.
\end{abstract}

Keywords: Dye yielding plants, Maharashtra, natural dyes

\section{INTRODUCTION}

In ancient times color was considered spiritual necessity of equal importance to the physical need of food. Since the very dawn of civilization, mankind has shown his liking and attraction of colors. Even in prehistoric days when man lived in caves, they used available natural dyestuff and pigment for coloring animal skin and their own skin during festivals as well as during wars (Rani et al. 2002). Because they believed that the color would give them magical powers, protect them from evil spirits and help them to achieve victory in war (Siva 2003). According to Dogan et al. 2003, from the beginning of 13th-century use of natural dyestuff by Phoenicians, Hebrews and Venetians were also started. According to Pal (2017) the description of natural dyes presents in Atharva Veda, Bhrigu Samhita was written using natural dyes, the frescos of Ajanta dating as far back as 1st century A.D. were painted with natural dyes while in epics like Ramayana and Mahabharata, Pitamber a yellow garment used for decorating idols of deity is evident. Before 2500 B.C., Henna was used as dye while in Bible a reference of Saffron as dye also mentioned. In China first report of natural dye extraction from plant sources dates back to around 2600 B.C. During the Indus valley civilization at Mohenjo-Daro and Harappa (3500 B.C.), it was found that color on clothing has been practiced (Siva 2007). In Egypt, it was also reported that peoples were used colored cloths for wrapping mummies. Chemical tests of red fabrics found in the tomb of King Tutankhamen in Egypt show the presence of alizarin, a pigment extracted from madder (Dangwal and Sharma 2011). It was also known that peoples of Aztec and Maya culture used dye obtained from insect such as Cochineal dye (Visalakshi and
Jawaharlal 2013).

Till the $19^{\text {th }}$ century, natural dyes were used to dye textile, leather, furs, hairs, feathers, matting, basketry, bone, and ivory. In 1856, William Henry Perkin (Germany) accidentally discovered Mauveine, a synthetic colorant. With the advent of synthetic dyes competes with natural dyes and almost completely replaced the latter within a century (Maxia et al. 2013). But in the last century use of synthetic dyes were disseminated throughout the world because of low cost, wide range of colors, greater reproducibility, and fastness. In recent years the adverse effects of these artificial colorants are getting highlighted. Productions of synthetic dyes make use of petrochemical source, and some of these dyes contain carcinogenic amines (Haji 2011). Synthetic materials and their products are more complex; it will take a long time for decomposing and return to nature hence causes environmental pollution (Lal et al. 2011). The synthetic dyes or their intermediates like anthraquinone, azo, triarylmethane, etc. are potential carcinogenic or genotoxic compounds (Barański et al. 1992). Research has shown that most of the synthetic dyes cause health-related problems, as it decreases food intake capacity, growth and fertility rate, causes damage to liver, spleen, kidney, and heart; inflicts lesions on skin, eyes, lungs and bones (Sinha et al. 2012). Furthermore, synthetic dyes are failed to qualify environmental standards imposed by countries worldwide, this has led to the increasing demand to the natural colorants in textile industries.

Natural dyes obtained from plants and animals are pigmentary molecules which impart colors to the material. These molecules contain aromatic ring structure coupled with azide chain are usually required for resonance and thus to impart color. There is correlation of chemical 
structure with color, chromogen - chromophore with auxochrome. For textile coloration chromophore and auxochrome are considered as most important chemical constituents of dyes (Trotman 1984; Foulds 1995). Natural dyes are eco-friendly, biodegradable and non-allergic as derived from natural resources. Most of the dyes are used known for their medicinal properties among Ayurvedic practitioners. In ancient time, in India different flowers like Seuli (Nyctanthes arbortristis L.), Palash (Butea monosperma (Lam.) Taub.) etc. used in Holi festivals and in those days this festival was safe because the natural dyes were not harmful to the human body (Das and Mandal 2012). Natural dyes are having anticancerous, antiinflammatory and antimicrobial properties. Curcumin from Curcuma longa L., Lawsone from Lawsonia inermis L., Punicalagin from Punica granatum L. are known to possess antimicrobial properties and also dyes from Acacia catechu (L.f.) Willd., Quercus infectoria Oliv., Rubia cordifolia L. and Rumex maritimus L. exhibited antimicrobial activity against pathogenic bacteria (Singh et al. 2005). These health beneficial features of natural dyes are due to flavonoids, tannins and other secondary metabolites. Natural dyes are also used in food products. One of the examples is lycopene-a red colored carotenoid pigment present in fruits likes tomato, watermelon, carrot used as color ingredient in many food products. Due to its possible role in the prevention of chronic diseases such as prostate cancer in recent year it has received considerable attention (Lawarence et al. 2015). Natural dyes are potential and possibly only alternative for more viable and safer dyeing in the textile industry. (Purohit et al. 2007).

Bulk of the natural dyes extracted from plant parts like flower, leaf, bark, fruits, seeds, animal sources, fungi, and lichens. Availability, color yield and reproducibility are the problems with natural dyes (Guljarani 2001). Particularly in India, natural dyes are being demanded not only for textile but also to be employed in food coloring, cosmetics and hair dye (Baliarsingh 2012). Reawakening interest in natural dyes is observed in "Naturally or International Symposium/Workshop on Natural Dyes" collaboratively organized by UNESCO and Crafts Council of India in 2006.

Only 150 coloring agents, out of 2000, produced by plants are exploited for dyeing purpose (Siva 2007). There is an urgent need to explore natural sources of dyes, identify new and rediscover traditional dyeing methods, and find out more precise and specific ways of applying natural dyes to get the required shades of color, and ensure colorfastness and examine the processes that have a potential for making natural dyes more eco-friendly and commercially important again. It is needed that research efforts should be directed towards exploring and bioprospecting of naturally available dye yielding resources. Das and Mondal (2012) attempted a survey of folk use of dye yielding plants and also its medicinal value from lateritic zone of West Bengal. Sutradhar et al. (2015) have documented the dye yielding plants of Tripura. Rashid (2013) accounts 48 plant species belongs to 40 genera and 27 families from Rajouri of Jammu and Kashmir. Lichens are excellent textile dyes; Shulka et al.
(2014) have cataloged 11 species of Himalayan lichen as source of natural dyes. Maharashtra, well known for its richness in biodiversity but very little dye yielding resources are documented. In this backdrop present study aims to generate baseline data on the dye yielding plants of Maharashtra state, India.

\section{MATERIALS AND METHODS}

\section{Scope and study area}

The present checklist includes flowering plants in Maharashtra used as a source of dye. It consists of plant resources that are native to region, also cultivated and introduced species are included. Area wise, Maharashtra is India's third largest state and second most populous state of India. It occupies geographical area of $307,313 \mathrm{~km}^{2}$. It is situated in the $15^{\circ} 60^{\prime}$ to $20^{\circ} 75^{\prime} \mathrm{N}$ latitude and $72^{\circ} 61^{\prime}$ to $74^{\circ} 40^{\prime}$ E longitude and comprises ca. $750 \mathrm{~km}$ of Western Ghats. The state shares its boundaries with Gujarat to the North-West, Madhya Pradesh to the North, Chhattisgarh to the East and Karnataka and Goa to the South. Maharashtra is divided into 36 districts and six administrative divisions. Biogeographically state has been classified into three provinces viz. The Konkan, Western Ghats or Sahyadri and The Maharashtra Plateau. The 'Konkan' is a narrow strip of coastal land lying between the Arabian Sea and the Western Ghats. The western side of the Konkan region has a coastal length of about $720 \mathrm{~km}$, whereas the width of this region ranges from 30 to $60 \mathrm{~km}$. The area of the Western Ghats of Maharashtra is known as 'Sahyadris', with a total length of $750 \mathrm{~km}$ and an average width of $80 \mathrm{~km}$. The western face of the Ghats is cut by deep ravines and canyons. Many of the peaks of the Western Ghats are more than $1400 \mathrm{~m}$ in height. The highest peak of Maharashtra is Kalasubai (1646 m) other important peaks are Salher (1567 m), Mahabaleshwar (1438 m), Saptashringi (1416 m) and Trimbekeshwar (1304 m). Tapti, Godavari, Bhima and Krishna are the main rivers of the state. The state has a tropical monsoon climate and it experiences four seasons during a year. The summer season is the March to May followed by rainy season from June to September. The post-monsoon season is the October to November and December to February is the winter. The temperature of the state varies between $10^{\circ} \mathrm{C}$ in winter and $43^{\circ} \mathrm{C}$ in the summer and relative humidity varies between $40-85 \%$. The total rainfall in different parts of Maharashtra is not uniform. There is heavy rainfall in the coastal region (about $2000 \mathrm{~mm}$ ), scanty in the central parts (about $500 \mathrm{~mm}$ ) and medium in the eastern parts (about $1000 \mathrm{~mm}$ ). Most of the soils in Maharashtra are formed from the Deccan traps generally from the augite or amygdaloidal basalt. These soils are black, dark brown or reddish in color. There are 16 forest types, which belongs to six forest type groups i.e. Tropical Semi-Evergreen, Tropical Moist Deciduous, Littoral and Swamp, Tropical Dry Deciduous, Tropical thorn, and Subtropical Broad lived Hill forests (Champion and Seth 1968). Since the pioneering phase of plant explorations in India, Maharashtra has attracted many renowned botanists. 


\section{Data retrieval}

The present checklist is an outcome of detailed literature consultation pertaining to natural dye resources (Krishnamurthy et al. 2002; Rani et al. 2002; Gokhale et al. 2004; Akimpou et al. 2005; Siva 2007; Kar and Borthakur 2008; Gaur 2008; Prabhu and Bhute 2012; Antima et al. 2012; Maxia et al 2013; Sharda and Rastogi 2013; Ozturk et al. 2013; Visalakshi and Jawaharlal 2013; Jarngal and Katoch 2014; Sutradhar et al. 2015; Patil and Shisode 2017; Kumari et al. 2018). The online databases, The Plant list (http://www.theplantist.org/), Tropicos (http://www.tropicos.org/) and IPNI (http://www.ipni.org/) were accessed for family name, plant names and bibliographical details. The distributional details of plants were obtained through state floras as Flora of Maharashtra by M. R. Almeida (1996) and the Flora of Maharashtra State by Botanical Survey of India (Singh et al. 2001). Almost all the available district and regional floras were also consulted which includes Flora of Osmanabad (Naik 1979), Flora of Nagpur district (Ugemuge 1986), Flora of Akola district (Kamble and Pradhan 1988), The flora of Savantwadi (Almeida 1990), Flora of Nasik district (Lakshminarasimhan and Sharma 1991), Flora of Buldhana district (Diwakar and Sharma 2000), Flora of Mahabaleshwar and adjoining (Deshpande et al. 1993), Flora of Yavatmal district (Karthikeyan and Kumar 1993), Flora of Marathwada (Naik 1998), Flora of Ahmednagar district (Pradhan and Singh 1999), Flora of Kolhapur district (Yadav and Sardesai 2002), Flora of Dhule and Nandurbar district (Patil 2003), Flora of Jalgaon district (Kshirsagar and Patil 2008), Flora of Baramati district (Bhagat et al. 2008), Flora of Solapur district (Gaikwad and Garad 2015).

\section{RESULTS AND DISCUSSION}

The present study is a first attempt to compile a statewide list of dye yielding flowering plant resources. The data compiled as botanical names, family, plant part used, dye color and coloring agents are listed in table 1. A total of 195 dye yielding species belonging to 153 genera and 58 families has been reported in the present work. The listed plant species belong to 52 families of Dicotyledons and 5 families of Monocotyledons. The highest number of dyes yielding species found in family Fabaceae with 44 species followed by Asteraceae, Malvaceae, and Moraceae with 9 species, Rosaceae with 7 species and Zingiberaceae with 6 species. There are 6 families (Amaranthaceae, Anacardiaceae, Apocynaceae, Combretaceae, Meliaceae, Solanaceae, etc.) having 5 species, 3 families (Boraginaceae, Euphorbiaceae, Lythraceae) having 4 species and 7 families (Casuarinaceae, Myrsinaceae, Phyllanthaceae, Rhamnaceae, Rhizophoraceae, Rutaceae, Sapotaceae etc. having 3 species and remaining families are with minimum number of species. (Figure 1). The genera represented by higher number of species were Acacia (7 species), Terminalia (5 species), Curcuma, Ficus, Indigofera and Senna (4 species), Bauhinia and Caesalpinia (3 species) and rest of genera with minimum number of species.


Figure 1. Family wise distribution of dye yielding plants from Maharasthra, India

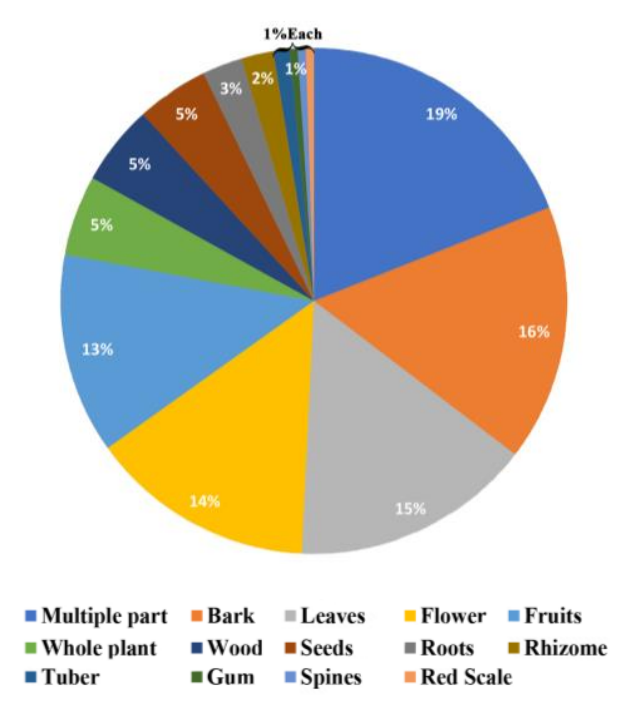

Figure 2. Percentage use of different plant part for use of dye

Dye yielding plant parts percentage found to be, bark $(16 \%)$, leaves $(15 \%)$, flower $(14 \%)$ fruit $(13 \%)$, wood $(5 \%)$, seed $(5 \%)$, roots $(3 \%)$, rhizome $(2 \%)$, tuber $(1 \%)$, gum $(1 \%)$, spines $(1 \%)$, and red scales $(1 \%)$ were found in use as source of coloring material. (Figure 2.) There were 37 species with more than one plant part in use. The important dye extracted from roots or underground plant parts including Amaranthus spinusus L., Ampelocissus latifolia (Roxb.) Planch., Beta vulgaris L., Curcuma angustifolia Roxb., Curcuma aromatica Salisb., Curcuma longa L., Curcuma zedoria (Christm.) Roscoe., Toddalia asiatica (L.) Lam., Zingiber officinale Roscoe. etc. Rind of fruits from Acacia nilotica (L.) Delile., Punica granatum L., Terminalia arjuna (Roxb. ex DC.) Wight \& Arn., Terminalia chebula Retz. are also used for extracting dyes. 
Fruit pulp of Garcinia spicata Hook. f., Phyllanthus emblica L. also made into dyes. Coir from Cocos nucifera L., Gum of Delonix regia (Bojer ex Hook.) Raf., Spines of Bombax ceiba and also wood ash of Euphorbia tirucalli L. used for dye extraction. While in species such as Amaranthus hypochondriacus L., Cuscuta reflexa Roxb., Eclipta prostrate (L.) L., Indigofera tinctoria L., Xylaria xylocarpa Taub. all parts used for dye extraction. Scientifically, the real nature of dye color varies from plant to plant and their parts. Range of colors to be maintained by the potential species is wide. They exhibit colors such as brown, yellow, purple, violet, pink, red, green, blue, orange, grey, etc.

Previous studies, from Maharashtra recorded are either for local regions or for specific taxa. Most of the reports are ambiguous or erroneous. Patil and Shisode (2017) have documented 53 Angiosperm species as natural dye yielding sources in Khandesh region. Gokhale et al. (2004) reported 500 dye types from indigenous species from India. Among other considerable studies Siva (2007) reported 88 dye resources. Among the considerable studies from other states of India include, Tiwari and Bharat (2008) have recorded 33 dye yielding resources from AchanakmarAmarkantak Biosphere reserve, Chhattisgarh. Kar and Borthakur (2008) have reported 47 dye yielding plants from Assam. Sutradhar et al. (2015) have made an attempt to document dye yielding plant resources from Tripura, which incorporates 39 species distributed under 35 genera and 26 families.

The present findings record Fabaceae as a most dominant natural dye yielding family, which is in congruence with studies by Nidhi and Katoch (2014), Sutradhar et al. (2015) and Singh (2017). Almost all of the plant parts yield dye, although in present report shows that bark, leaves, flowers, and fruits hold greater percentage of dye pigments. The same has been noticed by Nidhi and Katoch (2014) and Singh (2017).

In conclusion as the natural dyes are quite safe and economically viable, it needs to explore the sustainable utilization of these dyes for various practices. To know the real potential and availability of natural dye yielding resources more detailed studies and scientific investigations are necessary. It is revealed from present checklist that there are lots of dye yielding plants still untouched and information on dye pigments is lacking for most of the plants. Since the present checklist reports highest number of potential dyes yielding plant taxa. These dye resources must be utilized sustainably to extract natural dyes. Research efforts directed toward standardizing dye extraction methods, characterization and molecular elucidation of dyeing pigment will uplift the commercial values of natural dyes.

\section{ACKNOWLEDGEMENTS}

The authors are grateful to the Department of Botany, Shivaji University (SUK), Kolhapur, India for providing necessary facilities to carry out the work. One of the authors (PSH) is thankful to Shivaji University for the financial assistance in the form of Shivaji University Golden Jubilee Research Fellowship. We also thankful to Angiosperm Taxonomy Laboratory of the Department of Botany, SUK for providing floras. Sincere thanks to Dr. Manoj Lekhak and Sandip Gavade, Angiosperm Laboratory Department of Botany, SUK who heartedly cooperated by sharing their knowledge.

\section{REFERENCES}

Akimpou G, Rongmei K, Yadav PS. 2005. Traditional dye yielding plants of Manipur, North East India. Indian J Trad Knowledge 4: 33-38.

Almeida MR. 1996. Flora of Maharashtra. St. Xavier's College, Mumbai.

Almeida SM. 1990. Vol. I and Vol. II The Flora of Savantwadi Maharashtra, India. Scientific Publishers Jodhpur, India.

Antima S, Dangwal LR, Dangwal M. 2012. Dye Yielding Plants of the Garhwal Himalaya, India: A Case Study. Intl Res J Biol Sci 4: 69-72.

Baliarsingh S, Panda AK, Jena J, Das T, Das NB. 2012. Exploring sustainable technique on natural dye extraction from native plants for textile: Identification of colorants, colorimetric analysis of dyed yarns and their antimicrobial evaluation. J Clean Prod 37: 257-264.

Barański B, Przybojewska B, Spiechowicz E, Wyszyńska K, Zimnicki J.1992. Identification of potential carcinogenic dyes and intermediates on the basis of their genotoxicity. Medycyna Pracy 43: 469-77.

Bhagat RB, Shimpale VB, Deshmukh RB. 2008. Flora of Baramati. Pune.

Champion HG, Seth SK. 1968. A revised survey of the forest types of India. Manager of Publications, Delhi, India.

Dangwal LR, Sharma A. 2011. Indigenous traditional knowledge recorded on some medicinal plant in Narendra Nagar (Tehri Garhwal), Uttarakhand. Indian J Nat Prod Resour 2: 116-120.

Das PK, Mondal AK. 2012. Biodiversity and Conservation of Some Dye Yielding Plants for Justification of its Economic status in the Local areas of Lateritic Zone of West Bengal, India, Adv Biores 1: 43-53.

Deshpande S, Sharma BD, Nayar MP. 1993. Flora of Mahabaleshwar and adjoinings, Maharashtra. Botanical Survey of India, Calcutta.

Diwakar PG, Sharma BD. 2000. Flora of Buldhana district, Maharashtra. India. Botanical Survey of India, Calcutta.

Dogan Y, Başlar S, Mert HH and Ay G. 2003. Plants used as natural dye sources in Turkey. Econ Bot 57: 442-453.

Foulds J. 1995. Dyeing and Printing. A Handbook on Small Scale Textiles. Intermediate Technology Publications, London.

Gaikwad SP, Garad KU. 2015. Flora of Solapur district. Tatis Enterprises and Publishers, New Delhi.

Gaur R, 2008. Traditional dye yielding plants of Uttarakhand, India. Nat Prod Rad 7: 154-165.

Gokhale SB, Tatiya AB, Bakliwal SR, Frsule RA. 2004. Natural dye yielding plants in India. Nat Prod Rad 3: 228-234.

Gulrajani ML. 2001. Present status of natural dyes. Indian J Fibre Text Res. 26: 191-201.

Haji A. 2011. Antibacterial dyeing of wool with natural cationic dye using metal mordants. Mater Sci (Medžiagotyra) 18: 1392-1320.

Jarngal N, Katoch KN. 2014. Herbal Dye Yielding Plants of District Kathua, Jammu And Kashmir State, India. Intl Res J Biol Sci 3: 7379.

Kamble SY, Pradhan SG. 1988. Flora of Akola district. Botanical Survey of India, Calcutta.

Kar A, Borthakur SK. 2008. Dye yielding plants of Assam for dyeing handloom textile products. Indian J Tradit Know. 7 :166-171.

Karthikeyan S, Kumar A. 1993. Flora of Yavatmal District, Maharashtra, Botanical Survey of India, Calcutta.

Krishnamurthy KV, Siva R, Kumar TS. 2002. Natural dye-yielding plants of Shervaroy Hills of Eastern Ghats. Proceedings of the National Seminar on Conservation of Eastern Ghats, March 24-26, 1998, Kalavani Port Auditorium, Visakhapatnam, Andhra Pradesh, India.

Kshirsagar SR, Patil DA. 2008. Flora of Jalgaon district, Maharashtra. Bishen Singh Mahendra Pal Singh Publishers and Distributers, Dehradun, India.

Kumari P, Seth MK, Gagotia R. 2018. Dye Yielding Woody Plants along the National Highway from Parwanoo to Kaurik in Himachal Pradesh. Saudi J Life Sci 3:134-139.

Lakshminarasimhan P, Sharma BD. 1991. Flora of Nasik District. Botanical Survey of India, Calcutta. 
Lal C, Sharma MC, Shakyawar DB, Raja ASM, Sharma KK, Pareek PK 2011. Natural dye constituents from rind of Punica granatum and its application on Pashmina fabrics. Arch Appl Sci Res 3: 350-357.

Lawrence B, Mahesh S, Aswathy JM, Murugan G, Murugan K. 2015. Ethnic knowledge of dye yielding plants used by the Kani tribes of Ponmudi hill: A case study. Indo Amer J Pharmaceut Res 5: 26112616.

Maxia A, Meli F, Gaviano C, Picciau R, Martis BD, Kasture S, Kasture V. 2013. Dye plants: Natural resources from traditional botanical knowledge of Sardinia Island, Italy. Indian J Tradit Know 12: 651656.

Naik VN. 1979. Flora of Osmanabad. Venus Publishers, Aurangabad, India.

Naik VN. 1998. The Flora of Marathwada. Amrut Publication, Aurangabad, India.

Ozturk M, Uysal I, Gucel S, Altundag E, Dogan Y, Baslar S. 2013. Medicinal uses of natural dye-yielding plants in Turkey. Res J Tex Appl 17: 69-80.

Pal A. 2017. Chemical Investigation on Selected Indigenous Plants for Natural Dyes and Dyeing Characteristics. [Dissertation]. Forest Research Institute (Deemed), University Dehradun, Uttarakhand.

Patil DA, SB Shisode. 2017.Natural dye: Yielding vegetable sources in Khandesh region (Maharashtra) India. Intl J Adv Res Dev 2: 18-21

Patil DA. 2003. Flora of Dhule and Nandurbar district, Maharashtra. Bishen Singh Mahendra Pal Singh Publishers and Distributers, Dehradun, India.

Prabhu KH, Bhute AS. 2012. Plant-based natural dyes and mordants: A Review. J Nat Prod Plant Resour 2: 649-664.

Pradhan SG, Singh NP. 1999. Flora of Ahmednagar District, Maharashtra. Bishen Singh Mahendra Pal Singh, Dehradun. India.

Purohit A, Mallick S, Nayak A, Das NB, Nanda B, Sakio S. 2007. Developing Multiple Natural Dyes from Flower Parts of Gulmohur. Curr Sci 92: 168-182.

Rani SS, Murthy RKS, Pullaiah T. 2002. Dye yielding plants of Andhra Pradesh, India. J Econ Tax Bot 26: 740-749.
Rashid A. 2013. Dye yielding plant diversity of district Rajouri Jammu and Kashmir state-India. Intl J Pharm Bio Sci 1: 263-266.

Sharda NL, Rastogi D. 2013. Unexplored treasure of the Garhwal Himalayas: Dye yielding Plants for sustainable dyeing. J Acad Ind Res 2: 155-159.

Shulka P, Upreti DK, Nayakas S, Tiwari P. 2014. Natural dyes from Himalayan lichens. Indian J Tradit Know 13: 195-201.

Singh NP, Lakshminarasimhan P, Karthikeyan S and Prasanna PV. 2001. Flora of Maharashtra State. Botanical Survey of India, Calcutta.

Singh R, Jain A, Panwar S, Gupta D, Khare SK. 2005. Antimicrobial activity of some natural dyes. Dyes Pigm 66: 99-102.

Sinha K, Saha PD, Datta S. 2012. Extraction of natural dye from petals of Flame of forest (Butea monosperma) flower: Process optimization using response surface methodology (RSM). Dyes Pigm 94: 212-216.

Siva R. 2003. Assessment of genetic variation in some dye-yielding plants using isozyme data. [Dissertation]. Bharathidasan University, Tiruchirapalli, India.

Siva R.2007. Status of natural dyes and dye yielding plants in India. Curr Sci 92: 916-925.

Sutradhar B, Deb D, Majumdar K. 2015. Traditional dye yielding plants of Tripura, Northeast India. Biodiversitas 16: 121-127.

Tiwari SC, Baharat A.2008. Natural dye yielding plants and Indigenous knowledge of dye preparation in Achanakmar- Amarkantak Biosphere reserve Central India. Nat Prod Rad 7: 82-87.

Trotman ER. 1984. Dyeing and Chemical Technology of Textile fibres. 6 th ed. Griffin, London.

Ugemuge NR. 1986. Flora of Nagpur District, Maharashtra, India. Shree Publication, Nagpur.

Visalakshi M, Jawaharlal M. 2013. Healthy Hues-Status and Implication in Industries-Brief Review. J Agric Allied Sci 2: 42-51.

Yadav SR, Sardesai MM. 2002. Flora of Kolhapur District. Shivaji University, Kolhapur. 
Table 1. Dye yielding plants of Maharashtra, India

\begin{tabular}{|c|c|c|c|c|c|}
\hline $\begin{array}{l}\text { Botanical Name and } \\
\text { Family }\end{array}$ & $\begin{array}{l}\text { Part/s } \\
\text { used }\end{array}$ & Color & Pigment & Reference & Distribution \\
\hline \multicolumn{6}{|l|}{ Acanthaceae } \\
\hline Barleria prionitis L. & Flowers & Yellow & & & $\begin{array}{l}\text { Along hedges. Common. Ahmednagar, Akola, Aurangabad, Beed, Bombay, } \\
\text { Chandrapur, Dhule, Jalna, Jalgaon, Kolhapur, Nagpur, Nanded, Nasik, } \\
\text { Osmanabad, Parbhani, Pune, Raigad, Ratnagiri, Satara, Sindhudurg, Thane, } \\
\text { Yavatmal. }\end{array}$ \\
\hline Justicia adhatoda L. & Leaves & $\begin{array}{l}\text { Orange, } \\
\text { yellow/green }\end{array}$ & $\begin{array}{l}\text { Adhatodic acid, } \\
\text { Carotene, Luteolin, } \\
\text { Quercetin. }\end{array}$ & Sutradhar et al. 2015 & $\begin{array}{l}\text { Usually found as a hedge plant along roadsides. Ahmednagar, Aurangabad, } \\
\text { Beed, Chandrapur, Dhule, Jalgaon, Jalna,Latur, Kolhapur, Nagpur, Nanded, } \\
\text { Osmanabad, Parbhani, Pune, Raigad, Ratnagiri, Satara, Sindhudurg, Thane. }\end{array}$ \\
\hline
\end{tabular}

\section{Amaranthaceae}

Achyranthes aspera L. Whole Black/ Brown

Amaranthus

hypochondriacus $\mathrm{L}$.

Amaranthus spinosus L. Roots Pink (Auxillary)

Beta vulgaris $\mathrm{L}$ Roots Red

Celosia argentea $\mathrm{L}$ Flowers Pink, Red

\section{Amaryllidaceae}

Allium cepa $\mathrm{L}$.

Red scales Yellow, Brown, Carotenoid

Bright Red

\section{Anacardiaceae}

Anacardium occidentale L. Pericarp Black

$\begin{array}{llll}\begin{array}{l}\text { Lannea coromandelica } \\ \text { (Houtt.) Merr. }\end{array} & \text { Bark, } & \text { Yellow, Brown } & \\ \text { Mangifera indica } \text { L. } & \text { Fruits } & & \\ & \text { Bark, } & \text { Black } & \text { Mangiferin. } \\ & \text { Leaves } & & \end{array}$

Semecarpus anacardium L.f. Fruits Grey, Back Bhilawanol

Spondias pinnata (L. f)

Kurz.
Black
Gokhale et al. 2004

Sutradhar et al.2015

Gokhale et al. 2004

Siva, 2007
Rare in swampy habitat. Chandrapur, Kolhapur, Nanded, Nasik.

Occasional on wastelands and around fields. Aurangabad \& Beed.

Common in open areas and waste places as a weed.

Cultivated in many parts for fleshy roots used in salad, vegetables etc.

The familiar Cocks comb is planted in gardens.

Widely cultivated. Ahmednagar, Buldhana, Chandrapur, Nagpur, Osmanabad, Pune, Satara, Sindhudurg, Thane.

Usually planted, occasionally found as an escape in deciduous forests. Ahmedngar, Bombay, Chandrapur, Kolhapur, Nasik, Pune, Raigad, Ratnagiri, Satara, Sindhudurg, Thane.

Common throughout in deciduous forests.

Commonly cultivated, sometimes found wild.

Common throughout in deciduous forests.

Occasional in hill forests and around fields. Ahmednagar, Aurangabad,

Bombay, Latur, Nagpur, Nasik, Pune, Raigad, Ratnagiri, Thane. 


\section{Annonaceae}

Annona reticulata $\mathrm{L}$.

Holarrhena pubescens Wall. ex G. Don Leaves Blue

Apocynaceae

Nerium indicum Mill.

Roots, Bark

Red

Tabernaemontana divaricata (L.) R.Br. Seeds

ex Roem. \&Schult.

Wrightia arborea (Dennst.) Mabb.

Seeds, Roots $\quad$ Yellow

Wrightia tinctoria $\mathrm{R} . \mathrm{Br}$

Leaves

Blue

\section{Aracacea}

Areca catechu $\mathrm{L}$.

Cocos nucifera $\mathrm{L}$

Nuts

Coir

Brown

\section{Asphodelaceae}

Agave americana $\mathrm{L}$.

Aloe vera (L.) Burm.f.

Leaves

Whole plant

Laxative

Red

\section{Asteraceae}

Artemisia japonica Thunb.

Caesulia axillaris Roxb.

Carthamus tinctorius $\mathrm{L}$

Whole Plant Yellow

Flowers Yellow, Red

Flowers $\quad$ Yellow

Coreopsis tinctoria Nutt.

Cosmos bipinnatus Cav.

Eclipta prostrate $\mathrm{L}$.

Helianthus annuus $\mathrm{L}$

Tagetes erecta $\mathrm{L}$.

Wedelia chinensis (Osbeck) Merr.

Yellow

Flowers Yellow
Dry unripe fruits Black
Catechin

Indigo yielding glucoside.
Gokhale et al. A native of Tropical America. Usually cultivated but also 2004 occurs as an escape.

Common throughout the state in dry deciduous and semievergreen forests.

Grown in gardens for showy Flowers, sometimes found as an escape.

Grown in the gardens.

Common in moist forests. Akola, Amravati, Chandrapur, Kolhapur, Nanded, Nasik, Pune, Raigad, Ratnagiri, Thane. Gokhale et al. Common throughout the state in dry and moist deciduous 2004 forests.

Cultivated. Southern Konkan.

Kolhapur.

Chandur, Ingali, Kodoli, Rui, Wasagade.

Scattered in waste places, road sides and along hedges. Ahmednagar, Akola, Buldhana, Nagpur, Nasik,

Osmanabad, Pune, Satara, Thane.

A few along forest edges. Raigad, Pune, Satara

Kagal, Kolhapur, Shiroli.

Carthamin, Carthamon.

Gokhale et al. Safflowers, a native of S.W. Asia is cultivated in the black 2004 soil districts of Bombay Presidency, for the use of dyers as well as for oil extracted from Seeds.

A native of N. America, grown in gardens.

Apigenin

Phenols, coumarins, flavones

Native of Mexico, grown in gardens. Marathwada, Nasik.

Flowers Yellow, Violet

Quercetagetin

Sutradhar et al. Common throughout in wet situations

2015

The Common Sunflowers native of Western USA, is cultivated throughout for oil Seeds.

Singh and The African Marigold, a native of Mexico is grown

Bharati.2014 abundantly in gardens.

Rare. 'Konkan'. 


\section{Balsaminaceae}

Impatiens balsamina $\mathrm{L}$.

\section{Basellaceae}

Basella alba L.

Seeds

Gomphrenin-I

\section{Bignoniaceae}

Kigelia africana (Lam.) Benth.

Wood, roots

Grayish

brown

Spathodea campanulata P. Beauv.

Leaves

Orange

\section{Bixaceae}

Bixa orellana $\mathrm{L}$.

\section{Boraginaceae}

Cordia domestica Roth.

Ehretia laevis Roxb.

Heliotropium indicum $\mathrm{L}$.

Heliotropium strigosum Willd.

Black

\section{Brassicaceae}

Brassica oleracea $\mathrm{L}$.

\section{Burseraceae}

Garuga pinnata Roxb.

\section{Casuarinaceae}

Casuarina equisetifolia $\mathrm{L}$.

Bark

Light Reddish Brown

\section{Clusiaceae}

Garcinia spicata Hook. f

Garcinia xanthochymus Hook. f
Monoglycosidic anthocyanin based on pelargonidin. 2004

Sutradhar et al. As an escape throughout the State. Also grown extensively 2015 as vegetable and makes a good spinach.

Commonly planted as avenue trees and also grown in gardens.

Commonly planted as avenue tree.

Siva, 2007. It is a native of Tropical America. Commonly cultivated.

Infrequent in deciduous forest. 'Konkan'.

Frequent in deciduous forests. Ahmednagar, Chandrapur, Dhule, Kolhapur, Nagpur, Nasik, Pune, Raigad, Ratnagiri, Sindhudurg.

Frequent in open, moist places as weed. Bombay, Dhule, Nagpur, Nasik, Pune, Ratnagiri, Satara, Sindhudurg, Thane.

Frequent in open areas and in fallow fields in plains in

deciduous forests. Chandrapur, Sindhudurg.

Cultivated in many parts for its Flowers which are used as vegetable.

In deciduous forests. Common throughout the state.

Widely distributed from south East Asia to Pacific Islands to North and North East Australia. Cultivated widely in tropics, mostly naturalized in India.

Singh and Bharati.2014
Rare in semi-evergreen forests. Ahmednagar, Ratnagiri,

\section{Sindhudurg.}

Occasional near streams in semi-evergreen to wet deciduous forests. Bombay, Kolhapur, Nagpur, Pune,

Sindhudurg. 


\section{Convolvulaceae}

\section{Dioscoreaceae}

\section{Dipterocarpaceae}

\section{Ebenaceae}

\section{Terminalia alata Roth.}

Terminalia arjuna (Roxb. ex DC.)

Wight \& Arn.

Terminalia bellirica (Gaertn.) Roxb.

Terminalia catappa $\mathrm{L}$

Terminalia chebula Retz.

Cuscuta reflexa Roxb.

Dioscorea bulbifera L.

Shorea robusta Gaertn.

Bark

Bark, Fruit rind Sandy, Khaki Red

Fruits

Leaves

Fruit rind

Brown, Black

Yellow, Black, Brown, Chebulinic acid Dark blue, Dark grey, Creamy Brown

\section{Whole plant Yellow}

\section{Tuber Pale color}

Bark

Red, Black

\section{Ellagic acid}

Arjunic acid ellagic acid

Ellagic acid
Diospyros melanoxylon Roxb.

Bark

Diospyros. peregrina (Gaertn.) Gürke

Black

Yellow

\section{Euphorbiaceae}

Chrozophora rottleri

(Geiseler)A.Juss.ex.Spreng.

Euphorbia tirucalli L.

Jatropha curcas L

\section{Fabaceae}

Acacia pennata Dalzell \& A. Gibson

Acacia caesia (L.)
Mallotus philippensis (Lam.) Müll.Arg. Fruit

\section{Bark}

Bark,

pods
Chebulaginic acid, gallic acid, Sutradhar et al. Common throughout.

Cuscutin, quercetin, coumarin Sutradhar et al. Common parasite on Bauhinia sp., Ficus sp., Ziziphus spp., 2015

\section{Common in all districts.}

Introduced as an omamental tree. Amravati.

Common in dry deciduous forests. Ahmednagar, Akola, Bombay, Chandrapur, Jalgaon, Nasik, Pune, Raigad, Satara, Thane, Yavatmal.

Found in moist \& semi-evergreen forests. Ahmednagar,

Chandrapur, Pune, Ratnagiri.

\section{Common.}

Frequent. Ahmednagar, Aurangabad, Mumbai, Buldhana, Pune, Ratnagiri, Thane. Frequent.

Rottlerin, isorottlerin

Sutradhar et al. Common.
Dark blue, Purple,

Yellow

Red, Orange
Black
Brown, Black 


\begin{tabular}{|c|c|c|c|c|c|}
\hline Acacia catechu (L.F.) Willd. & Heart wood & Brown, Red, Black & $\begin{array}{l}\text { Catechin, } \\
\text { Catechin red. }\end{array}$ & $\begin{array}{l}\text { Gokhale et al. } \\
2004\end{array}$ & Common in deciduous forests. \\
\hline Acacia chundra (Roxb. ex Rottl.) & Heart wood & Brown & & & Common throughout in dry deciduous forests. \\
\hline Acacia farnesiana (L.) Willd. & Bark, Fruits & Yellow & & & $\begin{array}{l}\text { Planted in hedges, also naturalized in some villages. } \\
\text { Bombay, Nasik, Pune, Osmanabad, Ratnagiri, Thane, } \\
\text { Yavatmal. }\end{array}$ \\
\hline Acacia leucophloea Willd. & Leaves, Bark & Red, Yellow & & & Common throughout in scrub forests. \\
\hline $\begin{array}{l}\text { Acacia nilotica subsp. Indica (Benth.) } \\
\text { Brenan. }\end{array}$ & Bark, Fruit rind & Brown, Black, Yellow & Catechin & $\begin{array}{l}\text { Gokhale et al. } \\
2004\end{array}$ & Dhule, Jalgaon, Marathwada, Pune, Solapur. \\
\hline Adenanthera pavonina $\mathrm{L}$. & Wood & Red & & & $\begin{array}{l}\text { Often planted, rarely wild in moist deciduous forests. } \\
\text { Bombay, Dhule, Jalgaon, Nagpur, Pune, Raigad. }\end{array}$ \\
\hline Aegle marmelos (L.) Corrêa & Bark & Red & & & $\begin{array}{l}\text { Common throughout in dry deciduous forests and also } \\
\text { planted. }\end{array}$ \\
\hline Albizia procera (Roxb.) Benth. & Bark & Brown & & & $\begin{array}{l}\text { Common. Akola, Chandrapur, Nasik, Pune, Raigad, } \\
\text { Yavatmal. }\end{array}$ \\
\hline Albizia odoratissima (L.f.) Benth. & Stem, Bark & Brown, Brick red & & & Common. \\
\hline Bauhinia purpurea $\mathrm{L}$. & Bark & Violet, Purple, Yellow & Chalcone, butein & $\begin{array}{l}\text { Gokhale et al. } \\
2004\end{array}$ & $\begin{array}{l}\text { Common in deciduous forests, also planted in gardens } \\
\text { and along roadsides. }\end{array}$ \\
\hline Bauhinia variegata $\mathrm{L}$. & Leaves & Purple & Anthocyanin & $\begin{array}{l}\text { Sutradhar et al. } \\
2015\end{array}$ & $\begin{array}{l}\text { Planted. Chandrapur, Nasik, Osmanabad, Pune, Satara, } \\
\text { Thane. }\end{array}$ \\
\hline Bauhinia. vahlii Wight \& Arn. & Bark & Brown, Black & & & $\begin{array}{l}\text { In moist deciduous forests. Frequent. Amravati, } \\
\text { Chandrapur, Nagpur, Pune, Raigad, Yavatmal. }\end{array}$ \\
\hline Butea monosperma (Lam.) Taub. & Leaves Flowers & Red, Yellow & $\begin{array}{l}\text { Butein, butin, isobutrin, } \\
\text { coreopsin, isocoreopsin }\end{array}$ & $\begin{array}{l}\text { Sutradhar et al. } \\
2015\end{array}$ & Common throughout in deciduous forests of the state. \\
\hline Butea superba Roxb. & Bark & Red & Glycosides, Butrin, Butein. & & $\begin{array}{l}\text { In moist and dry deciduous forests, frequent. Akola, } \\
\text { Amravati, Chandrapur, Dhule, Kolhapur, Nagpur, Nanded, } \\
\text { Nasik, Pune, Raigad, Thane, Yavatmal. }\end{array}$ \\
\hline Caesalpinia coriaria (Jacq.) Willd. & Fruits & Brown, Black & Ellagic acid & $\begin{array}{l}\text { Singh and } \\
\text { Bharati.2014 }\end{array}$ & Native of S. America \\
\hline Caesalpinia pulcherrima (L.) Sw. & Flowers & Pale violet & & & Planted in gardens. \\
\hline Caesalpinia sappan $\mathrm{L}$. & $\begin{array}{l}\text { Bark, Sapwood, } \\
\text { Pods. }\end{array}$ & Red, Black & Brazilin, Sappan red. & $\begin{array}{l}\text { Gokhale et al. } \\
2004 \text {. }\end{array}$ & Planted in gardens. Bombay, Kolhapur, Pune. \\
\hline Cassia fistula $\mathrm{L}$. & $\begin{array}{l}\text { Bark, Flowers, } \\
\text { Fruit }\end{array}$ & Brown, Black, Yellow & Leucoanthicynidin. & $\begin{array}{l}\text { Gokhale et al. } \\
2004 .\end{array}$ & $\begin{array}{l}\text { Common throughout the state in deciduous forests. Also } \\
\text { planted in home gardens }\end{array}$ \\
\hline Clitoria ternatea $\mathrm{L}$. & Leaves & Blue & Anthocyanin pigment ternatin & $\begin{array}{l}\text { Sutradhar et al. } \\
2015\end{array}$ & $\begin{array}{l}\text { Along hedges and also cultivated, common throughout the } \\
\text { state }\end{array}$ \\
\hline Delonix regia (Bojer ex Hook.) Raf. & Gum & Yellow & & & $\begin{array}{l}\text { Planted throughout the state along road-sides and in } \\
\text { gardens. }\end{array}$ \\
\hline Erythrina suberosa Roxb. & Flowers & Dark brown & & & In deciduous forests, frequent. \\
\hline Erythrina variegata $L$. & Flowers & Red & $\begin{array}{l}\text { Anthocyanin and betalains } \\
\text { pigment }\end{array}$ & $\begin{array}{l}\text { Sutradhar et al. } \\
2015\end{array}$ & In deciduous forests and also planted, common. \\
\hline $\begin{array}{l}\text { Flemingia macrophylla (Willd.) Kuntze } \\
\text { ex Merr. }\end{array}$ & Leaves, Bark & Black & & & $\begin{array}{l}\text { In moist deciduous forests, frequent. Pune, Ratnagiri, } \\
\text { Satara, Thane, Yavatmal. }\end{array}$ \\
\hline Indigofera cassioides Rottler ex DC. & Leaves & Blue & & & In hilly forests, Common. \\
\hline Indigofera cordifolia B. Heyne ex Roth & Flowers & Black & & & Common throughout in plains in open situations. \\
\hline
\end{tabular}


Indigofera parviflora F. Heyne ex Hook. Leaves

Yellow

\& Arn.

Indigofera tinctoria $\mathrm{L}$

Whole plant

Indigo Blue

Indigotin

Peltophorum pterocarpum (DC.) Backer Wood, Leaves Brown black ex K. Heyne

Pithecollobium dulce Benth

Pongamia pinnata (L.) Pierre

Seeds

Black

Prosopis juliflora (Sw.) DC.

Pterocarpus marsupium Roxb. Pterocarpus santalinus L.f.

Senna alata (L.) Roxb.

Senna auriculata (L.) Roxb.

Senna occidentalis (L.) Link

Senna tora (L.) Roxb.

Tamarindus indica $\mathrm{L}$.

Tephrosia candida DC.

Tephrosia purpurea (L.) Pers

Trigonella foenum-graecum $\mathrm{L}$

Xylia xylocarpa Taub.

\section{Lamiaceae}

Leucas cephalotes (Roth) Spreng.

Tectona grandis L.F.

\section{Lauracea}

Cassytha filiformis L.

Brown

\section{Linaceae}

Reinwardtia indica Dumort.

Flowers

Yellow

Seeds Black

Fruits, Seeds and Red, Orange, Yellow

Seeds

Brown

Seeds

Yellow

Leaves

Grey, Brown

Leaves Red, light blue

Leaves Blue

$\begin{array}{ll}\text { Leaves } & \text { Yellow } \\ \text { Whole plant } & \text { Brown }\end{array}$

Seeds Auxillary

Wood Deep orange
In wastelands and as forest undergrowth, frequent 'Konkan', Osmanabad, Pune.

Sutradhar et al. Common throughout in plains, in open situations and also 2015 cultivated.

Planted in gardens and along road sides. Ahmednagar,

Bhandara, Bombay, Chandrapur, Osmanabad, Pune,

Raigad, Sindhudurg, Thane

Common.

Common throughout the state along the river banks, also cultivated.

Common along banks of rivers and on hill slopes. Akola,

Chandrapur, Dhule, Osmanabad.

In deciduous forests, common

In gardens, Thane. Occasionally introduced in gardens.

Wood $\quad$ Red $\quad$ Santalin

Tecto Leavesquinone

Chrysophanic acid, Emodin Singh and

Bharati 2014

Chrysophanic acid, Emodin Singh and

Bharati 2014

Singh and

$\begin{array}{ll}\text { Bharati } 2014 \\ \text { Chrysophanic acid, Emodin } & \text { Singh and }\end{array}$

Bharati 2014

Planted. Pune.

Along the drier tracts in open situations

Common, along the waste lands.

Common throughout the state in waste places.

As an escape in the outskirts of forests and also found planted around villages.

A native of Himalayas, W. Indo-China and Malay

Common throughout the waste places and plains.

Cultivated throughout for its leaves and seeds.

Chandrapur, Raigad, Ratnagiri, Satara.

Common throughout the State in the undergrowth and in open situations.

Sutradhar et al. Common in deciduous forests.

2015
Archipelago, occasionally planted in gardens. Pune.

Frequent in deciduous forests on hosts like Ipomoea spp., Vitex spp., etc. Amravati, Bhandara, Chandrapur, Nagpur, Pune, Ratnagiri, Sindhudurg, Thane, Yavatmal.

On hill tops, frequent. Kolhapur, Nasik, Pune, Raigad, Ratnagiri, Satara, Sindhudurg, Thane. 


\section{Loganiacea}

Strychnos nux vomica $\mathrm{L}$

Seed

Brown, Black

\section{Lythraceae}

Lagerstroemia parviflora Roxb.

Lawsonia inermis $\mathrm{L}$.

Bark

Punica granatum $\mathrm{L}$

Woodfordia fruticosa (L.) Kurz

Fruit rind

Flowers

Wood

Flowers

Malpighia glabra $\mathrm{L}$

\section{Malvaceae}

Abelmoschus esculentus (L.) Moench. Flowers

Flowers

Alcea rosea $\mathrm{L}$.

Bombax ceiba $\mathrm{L}$.

Gossypium herbaceum L.

Hibiscus rosa-sinensis L.

Spines

Flowers

Corolla

Kydia calycina Roxb.

Malva sylvestris L.

Bark

Leaves

Thespesia populnea (L.) Sol. ex Corrêa

Urena lobata $\mathrm{L}$.

Fruits

Wood
Yellow

Red

Brown, Yellow-Red Flavogallol.

Red orange, Reddish Lawsone. yellow

Yellow

Yellow

Purple

Brown, Red

Maroon

Green

Yellow

Brown

flavone
Scattered in forests, along roadsides and coasts. Kolhapur, Raigad, Ratnagiri, Sindhudurg.

Frequent in moist open situations, throughout Maharashtra. Sutradhar et al. Commonly cultivated.

2015

Gokhale et al. Planted for fruits throughout the state

2004

Gokhale et al. Common throughout.

2004

Usually planted as an ornamental tree near temples, rivers and gardens for its Flowers.

It is a Native of Texas. Grown in gardens.

Malvaceae

Cultivated in most districts of the state for its fruits which are used as vegetable. The species Asiatic in origin.

Cultivated in the Gardens for its showy Flowers

Ahmednagar, Aurangabad, Nagpur, Osmanabad, Pune,

Sindhudurg.

Common throughout the State in deciduous forests.

Sometimes planted.

Cultivated for its floss. Chandrapur.

Anthocyanidins, isoflavanol, Sutradhar et al. A native of Africa. Commonly cultivated in gardens.

2015

Bombay, Chandrapur, Nagpur, Osmanabad, Pune,

Ratnagiri, Sindhudurg, Thane.

Common in deciduous forests.

It is an ornamental usually grown in gardens and also found as an escape. Aurangabad, Bombay, Nagpur.

Wild along sea-shore and commonly cultivated along road sides.

Common in waste places and also along roadside. Amravati, Bhandara, Kolhapur, Nagpur, Pune, Raigad, Ratnagiri,

Satara, Sindhudurg, Thane. 


\section{Melastomataceae}

Melastoma malabathricum $\mathrm{L}$.

Leaves

Black purple

Memecylon umbellatum Burm. f.

Leaves

Yellow

\section{Meliaceae}

Aphanamixis polystachya (Wall.) R. Ba

Parker

Azadirachta indica A.Juss.

Bark

Dark green

Chukrasia tabularis A. Juss.

Soymida febrifuga (Roxb.) A. Juss Toona hexandra M. Roem.

\section{Moraceae}

Artocarpus heterophyllus Lam.

Wood

Leaves, Bark

Brown

Artocarpus lacucha Buch. -Ham. ex D. Flowers

Don.

Ficus amplissima $\mathrm{Sm}$

Bark

Ficus benghalensis $\mathrm{L}$.

Bark

Bark

Bark

Ficus religiosa $\mathrm{L}$

Morus alba L.

Leaves

Bark, Wood

Stem, Flower

Musaceae

Musa $\times$ paradisiaca $\mathrm{L}$.

\section{Myrsinaceae}

Ardisia solanacea Roxb.

Psidium guajava L.

Fruits

Fruit

Syzgyium cumini (L.)
Bark, Seeds
Black, Red

\section{Red, Brown}

Brown, Red

Yellow Morin

Yellow

Light, Red

Red, Brown

Auxillary

Green, Brown, Black

Yellow

Morin

Yellow

Black, brownish red

Black, Puple, Indigo.
Usually found in moist and semi-evergreen to evergreen forests. Chandrapur, Ratnagiri, Satara, Sindhudurg. Found in moist and semi-evergreen forests. Ahmednagar, Bombay, Chandrapur, Kolhapur, Nasik, Pune, Raigad,

Ratnagiri, Satara, Sindhudurg, Thane.

In evergreen forests. Bombay, Pune, Sindhudurg.

Planted. Common throughout the state along the roadsides and in gardens. Sometimes naturalized through selfpropagation

In evergreen forests. Sometimes found planted also.

'Konkan', Pune, Raigad, Sindhudurg.

Common. In deciduous forests.

In moist deciduous forests. Dhule, Nanded, Pune, Raigad, Ratnagiri, Satara, Sindhudurg.

Singh and Commonly cultivated, but naturalised. Bombay, Nasik, Bharati.2014 Pune, Raigad, Ratnagiri, Satara, Sindhudurg, Thane. Common in forest areas. Sindhudurg.

In forest areas, common.

Along road sides in towns and villages also found in low land forests, common.

Along streams and also along rocky hill-slopes, common. Forest outskirt, mostly near villages and usually planted near temples. Worshipped by Buddhists and Hindus

Singh and Planted in Kitchen gardens for lacidu lour. sweet edible

Bharati.2014 sorosis. Bombay, Dhule, Kolhapur, Marathwada (Naik, op. cit.), Pune, Satara, Thane.

In low land forests, rare. Bombay.

Amba, Borbet, Chandgad, Dindewadi, Here, Kolhapur, Radhanagari.

Frequent. Bombay, Kolhapur, Pune, Ratnagiri, Sindhudurg.

Guajanoic acid, carotenoids, Sutradhar et al. Cultivated in gardens

lectins, leucocyanidin 2015

In deciduous and semi-evergreen forests. Common

throughout. 
Bougainvillea glabra Choisy.

\section{Mirabilis jalapa $\mathrm{L}$}

\section{Oleaceae}

Jasminum sambac (L.) Aiton

Nyctanthes arbor-tristis $\mathrm{L}$.

Corolla

Green, Yellow, Orange

Nyctanthin, carotenoids Iridoid glycoside.

Yellow, Orange, Red, Brown.

\section{Oxalis corniculata $\mathrm{L}$.}

Leaves

\section{Papaveraceae}

Papaver rhoeas $\mathrm{L}$.

Papaver somniferum $\mathrm{L}$.

Flowers

Flowers

Grey, Red

Purple

\section{Phyllanthaceae}

Bridelia stipularis (L.) Blume

Cleistanthus collinus (Roxb.) Benth.

Phyllanthus emblica L.

Fruit Black

Bark, Leaves, Black, Brown

Fruit

Fruit pulp

Green, Brown, Red

\section{Piperaceae}

Piper betle L.

Rumex nepalensis Spreng.

Leaves

Black, Blue

Root

Yellow green

Proteaceae

Grevillea robusta A.Cunn. ex R.Br. Flowers Yellow, Green
Quercetin- xyloside, Isorhamnetic.
Flavonoids, kaempferol,

ellagic acid and gallic acid piperol

are, wild and abundant in dry deciduous forests at Pench

2015 (Nagpur). Also found in Ahmednagar (cultivated), Nasik,

Sutradhar et al. Common.

2015

Piperitol, piperbetol, eugenol, Sutradhar et al. Cultivated for its leaves. Latur, Osmanabad, Pune, Sangli, 2015

Ventilagin.

Stem, root, bark Red violet

Root, Bark Chocklet
Ventilago denticulata Willd

Ventilago madraspatana Gaertn.
Gokhale et al. Common in moist deciduous forests. Pune (cultivated), Yavatmal.

Occurring as weed in gardens and on wet soil of waste places. Common throughout

Usually under cultivation. Nagpur, Pune.

It is widely cultivated and also grown in gardens for the poppy Seeds used as food and to produce an oil which is used for making medicines, candles and soaps. Pune.

Kolhapur, Raigad, Ratnagiri, Sindhudurg.

Scarce. Bhandara, Chandrapur, Nagpur, Yavatmal. Thane.

Bhandara, Pune.

Introduced in gardens \& planted along road.sides \&parks. Ahmednagar, Dhule, Kolhapur, Satara, Sindhudurg.

Common in deciduous forests.

subtropics and

dwarf pot plant.

Grown in garden. Ahmednagar. 


\section{Rhizophoraceae}

Bruguiera gymnorhiza (L.) Savigny

Ceriops tagal (Perr.) C.B. Rob.

Bark

Bark

Bark

Bark

Brown

Rhizophora mucronata Lam.

Chockle

\section{Rosaceae}

Prunus persica (L.) Batsch.

Pyrus communis $\mathrm{L}$

Leaves Green

Rubus niveus Thunb.

Gardenia jasminoides J. Ellis

Morinda citrifolia $\mathrm{L}$.

Morinda pubescens $\mathrm{Sm}$

Rubia cordifolia $\mathrm{L}$.

Leaves Yellow

Fruit

Fruits

Stem, Root

\section{Purple to Blue}

Root, Stem,Bark Yellow, Red

red.

Yellow

\section{Rubiacea}

Hymenodictyon orixense (Roxb.) Mabb. Leaves

\section{Rutaceae}

Chloroxylon swietenia DC.

Bark

Yellow

Citrus medica $\mathrm{L}$.

Toddalia asiatica (L.) Lam.

Bark

Black, Blue

Roots

Yellow

Yellow,Ochre to grey, Myricetin

Red brown, Bright red.

Red
2004

Rare, along the estuaries. Ratnagiri, Sindhudurg.

Common along tidal swamps. Bombay (Cooke, op. cit), Raigad, Ratnagiri, Sindhudurg, Thane.

Rare in mangrove forests. Ratnagiri, Sindhudurg.

Common along mangrove forests. Raigad, Ratnagiri,

Sindhudurg, Thane. Common along mangrove forests.

Raigad, Ratnagiri, Sindhudurg, Thane.

Native of China. Cultivated in Satara

An ornamental plant, commonly planted in

Mahabaleshwar, Satara

Restricted to high ghats. Satara.

Native of China. Pune, Sindhudurg.

Gokhale et al. Usually cultivated, grows as an escape. Akola, Bombay,

2004

Jalgaon, Nagpur, Pune, Ratnagiri, Thane

Common throughout

Morindone

Manjistin, Purpurin

Sutradhar et al. Frequent in shady places in deciduous forests

2015 Ahmednagar, Kolhapur, Nasik, Pune, Ratnagiri, Satara, Sindhudurg, Thane.

Infrequent in decidouous forests. Amravati, Chandrapur, Dhule, Nasik, Pune, Raigad, Satara, Thane.

Occassional in dry deciduous forests. Ahmednagar,

Chandrapur, Nagpur, Nanded, Pune, Raigad, Yavatmal.

Singh and

Bharati.2014

Siva R, 2007

Kolhapur, Pune, Satara, Sindhudurg.

Singh and

Bharati.2014

Occasional in moist forests. Thane.

Common in dry deciduous and moist deciduous forests. Ahmednagar, Bombay, Chandrapur, Jalgaon, Pune, Raigad, Thane-Economic. 
Osmanabad, Pune, Raigad, Ratnagiri, Yavatmal. Planted along roadsides and in gardens for its fragrant Flowers and edible fruits.

\section{Sapindacea}

Dodonaea viscosa Jacq.

Bark, Leaves Yellow, Brown

\section{Solanaceae}

Nicotiana tabacum $\mathrm{L}$

Fruits

Yellow, Red

Leaves

Green

\section{Santalum album Lam}

Solanum anguivi Lam.

Solanum nigrum $\mathrm{L}$.

Wood

Red

Fruit

Fruits

Black

\section{Symplocaceae}

Symplocos cochinchinensis (Lour) S. Bark

Moore

Symplocos racemosa Roxb.

Leaves

\section{Tamaricaceae}

Tamarix aphylla (L.) H. Karst.

Bark, Flower Auxillary

\section{Verbenaceae}

Duranta repens $\mathrm{L}$.

Leaves, Seeds Green, Orange

\section{Vitaceae}

$\begin{array}{lll}\text { Ampelocissus latifolia (Roxb.) Planch. } & \begin{array}{l}\text { Fresh roots } \\ \text { Leaves }\end{array} & \text { Black } \\ \text { Vitis vinifera } \mathrm{L} . & & \text { Yellow, green }\end{array}$

\section{Zingiberaceae}

Alpinia galanga (L.) Willd.

Roots, Stalk

Yellow Brown

Tuber
Yellow
Common in dry deciduous and scrub forests, also planted as a hedge plant

\section{Singh and A native of tropical America. Cultivated for its edible} Bharati.2014 berries. Nagpur, Nasik, Pune.

A striking garden plant and also important commercially as the source of tobacco. Cultivated in some parts of the region. Jalgaon, Kolhapur, Nasik, Osmanabad, Pune, Raigad, Satara, Thane.

Ahmednagar, Akola, Buldhana, Nasik, Pune, Ratnagiri, Raigad, Solapur, Thane, Yavatmal.

Common in moist deciduous forests.

Gallic acid, catechin, caffeic Sutradhar et al. Common throughout as a weed in open situations.

acid, epicatechin, rutin, and 2015

niringenin

Frequent in moist deciduous and semi.evergreen forests along higher ghats. Kolhapur, Pune, Raigad, Ratnagiri, Satara, Sindhudurg.

Scattered in moist deciduous and semi.evergreen forests. Ahmednagar, Pune, Ratnagiri, Satara, Sindhudurg, Thane.

Bombay (Cultivated tree, on alluvial sandy soils), Marathwada.

Common.

Common throughout in dry deciduous forests.

Kolhapur, Jaisingpur, Kondigre, Nimshirgaon,

Tamadalage.

Galangin, dioxyflavonol

Gokhale et al. Sindhudurg.

2004

Rare. Pune. 
Curcuma aromatic Salisb.

Curcuma longa $\mathrm{L}$.

Dried rhizome Yellow

Dried Rhizome Yellow

Curcuma zedoaria (Christm.) Roscoe Rhizome

Yellow

Zingiber officinale Roscoe.
Rhizome
Curcumin

albuminoids
Mumbai, Satara, Sindhudurg.

Cultivated for the turmeric obtained from the Rhizomes,

but is doubtfully wild. Kolhapur, Nagpur, Osmanabad,

Sindhudurg.

Sutradhar et al. Cultivated. Bombay, Chandrapur, Raigad, Satara.

2015

Grown extensively in Ahmednagar, Nagpur, Osmanabad, Sindhudurg, Thane. 


\section{BIODIVERSITAS}

ISSN: 1412-033X

Volume 20, Number 1, January 2019

E-ISSN: 2085-4722

Pages: 250-266

DOI: $10.13057 /$ biodiv/d200129 